The Commission was informed of the progress made in the "major study" on the reappraisal of the role of the Red Cross. It also discussed the proposed 1975 conference on the theme "the Red Cross and peace".

Lastly, the Commission discussed some of the current activities of international Red Cross institutions.

\title{
A JOINT ICRC-LEAGUE INFORMATION KIT
}

At the Third General Meeting of Heads of Information and Public Relations Services of National Societies, ${ }^{1}$ at Varna (Bulgaria) in June 1973, the desire for closer co-operation between Red Cross national and international Information Services was expressed. The ICRC and the League have therefore decided to issue jointly, several times a year, an information "kit" in French, English and Spanish.

The " kit", entitled Contact, will provide National Societies with news, articles and photographs which they may use for their own publications or submit to the press, so as to give them the widest possible publicity. The first issue, which appeared in April, contained six contributions ranging from a description of relief work by the Icelandic Red Cross to a report-given in a later page of this Review-on international Red Cross assistance in the Democratic Republic of Vietnam.

\footnotetext{
${ }^{1}$ See International Review, August 1973. pp. 431 et seq.
} 